\title{
Urban Energy System Analysis Based on Scenario Settings
}

\author{
Wenjing $\mathrm{He}^{1, \mathrm{a}}$, Philip Jones ${ }^{2, \mathrm{~b}}$, Xiaojun $\mathrm{Li}^{3, \mathrm{c}}$ and Shanshan $\mathrm{Hou}^{4, \mathrm{~d}}$ \\ ${ }^{1}$ Shandong Jianzhu University, Jinan, China, \\ ${ }^{2}$ Welsh School of Architecture, Cardiff University, Cardiff, United Kingdom \\ ${ }^{3}$ Welsh School of Architecture, Cardiff University, Cardiff, United Kingdom \\ ${ }^{4}$ Welsh School of Architecture, Cardiff University, Cardiff, United Kingdom

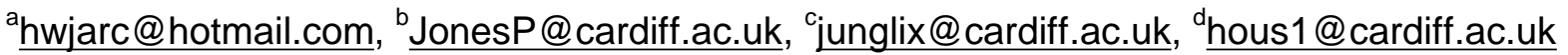

\begin{abstract}
Keywords: Energy performance, Energy analysis, New ecological city, Scenario setting, Energy resource structure
\end{abstract}

\begin{abstract}
In contemporary urban construction, the priority is to conform to the urban development needs in accordance with ecological and low-carbon requirements. At the initial stages of planning a new town, energy planning and analysis, and establishing sustainable energy development strategies are necessary to fulfil the requirements of an ideal ecological city. Therefore, to meet the urban planning requirements, energy planning often requires the determination of energy consumption index, and the knowledge of local energy demands and natural and social environments (to build a reasonable energy structure), adjusted through the evaluation, design, and optimization of the construction of ecological cities. This study explores energy planning through an analysis of the application of energy sources in the planning of the eco-city Jinan. Based on an investigation of the current situation, combined with the related national and local policies, laws, and regulations/standards, the energy consumption scenarios of the ecological city zone will be set up in the future; the energy demand will be forecasted, and an energy efficient and rational utilization plan will be made. In the process of energy planning, setting of energy scenarios and scenario analysis are the key activities in energy consumption forecasting.
\end{abstract}

\section{Introduction}

An eco-city is one in which the energy consumption, pollution, and emissions rates are low, thereby saving energy and enhancing environmental protection[1]. Currently, China is constructing a large number of new ecological cities to adapt to the growing economy and population for an ecological purpose. At the beginning of the planning process for a new town, it is important that energy planning is conducted to ensure that the goal of building an ecological city is fully realized[2]. In the design of the Xiuyuan ecological zone in Jinan city, China, the energy consumption analysis and optimization is adopted to fulfil the ecological goals.

Jinan City is located in central Shandong Province, and the Xiuyuan eco-city is located in the western area of the old Jinan city. The total area of the city is $23,750,000 \mathrm{~m}^{2}$, and the planned floor area is $28,700,000 \mathrm{~m}^{2}$. The land is mostly undeveloped, and the river flows through the center of the eco-city (refer with: Fig. 1, Fig. 2, Fig. 3).

\section{Research method}

The demand for a green eco-city is forecasted by the scenario analysis method, which is based on eco-city planning, research on energy consumption in the existing buildings, and an understanding and analysis of energy consumption in different types of buildings.

A scheme for renewable energy planning is proposed based on an assessment of renewable energy resources, such as solar energy, shallow geothermal energy, wind energy, and conventional coal and gas energy, in the total land area. 
The viability of various renewable energy sources is investigated by assessing the renewable energy that is suitable for the type of construction.

The type of renewable energy suitable for each area is also proposed. By making efficient and rational use of energy programs, the renewable energy sources in the ecological demonstration area and the municipal energy supply together bear the primary energy load in the region, through an efficient energy system and mode of operation.

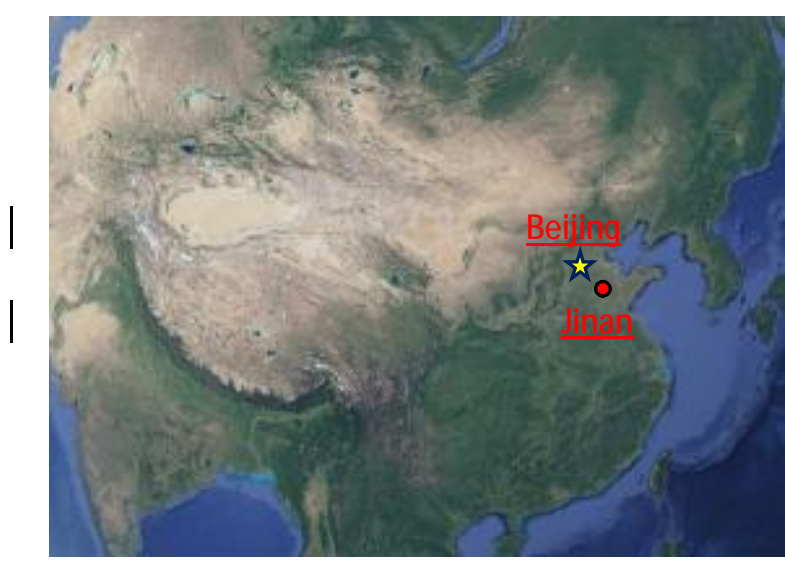

Fig 1. Location of the new ecological city

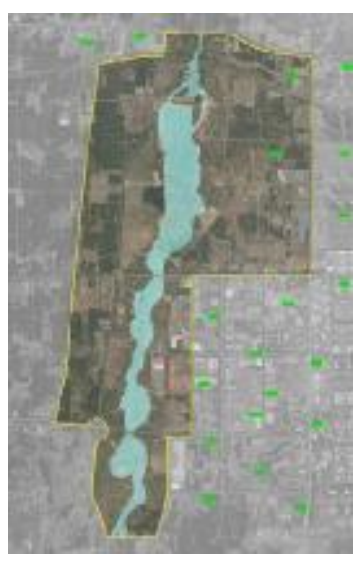

Fig. 2. Land status

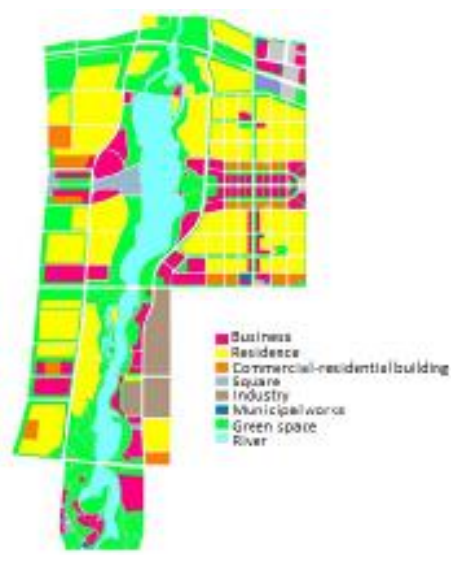

Fig. 3. Planning of land

\section{Basic scenario settings}

According to the construction status and requirements of China's policy standards [3,4,5], based on the buildings' energy consumption standards in 1980, short-term and long-term residential building constructions require energy savings of $75 \%$ and $80 \%$, respectively; new public buildings require energy savings of $65 \%$; and the status quo is to be maintained for the other buildings according to current research results. Recently, commercial gas consumption in public buildings has accounted for $60 \%$ of residential gas use, and long-term commercial gas consumption accounted for $100 \%$ of residential gas use. In the long-term, the gasification rate of gas-powered vehicles is also considered. Energy consumption in residential lands. Residential land buildings are divided into three categories: residential, basic education, and community services. The basic scenario parameters include the performance parameters of the thermal envelopes of short/long-term new buildings, indoor thermal envelopes (lighting, equipment, and personnel), indoor environmental control parameters, operation mode of the heating and air conditioning systems, and other parameters based on the "Shandong Province Residential Building Energy Efficiency Design Standards" (DBJ 14-037-2012)[6]. The conditions for maintaining the building energy consumption indicators are based on the research on the current conditions. The heating period of the buildings is 120 days, and the cooling period of the air conditioning system is 61 days.

The summer indoor temperature and humidity are set to $26{ }^{\circ} \mathrm{C}$ and $60 \%$, respectively, and the winter indoor temperature and humidity are set to $18{ }^{\circ} \mathrm{C}$ and $40 \%$, respectively. The room air exchange rate is once per hour to meet the comfort requirements.

The basic educational buildings include primary and junior high schools, and the air conditioning system is used from Monday to Friday with running periods of 08:00-12:00 and 14:00-18:00. In community service facilities, the air conditioning system runs continuously, and the daily running period is set to 08:00-21:00. 
Energy consumption in public building terminals.Public buildings include business offices, commercial buildings, municipal buildings, and other public facilities. The basic scenario parameters are similar to those of residential buildings.

Energy consumption in industrial and municipal buildings. Industrial facilities cover food processing, logistics, and transport sectors. The total area of industrial land is 12.9 ha. As only office energy consumption is considered, and the actual output value of industrial buildings is not included, only the energy consumption indicators in accordance with those for R\&D office buildings are calculated.

Municipal buildings mainly include postal services and telecommunications, transportation, and environmental sanitation; their energy consumption is similar to that of community service facilities; hence, their energy consumption targets were taken from those of the community service buildings.

\section{Energy demand forecast}

The energy consumption in the eco-city is divided into heating load, gas load, and electricity load. According to the regional energy demand, heating load includes building heating, production heating, domestic hot water, and summer air conditioning. Gas load includes residential cooking, commercial cooking, industrial, gas-fired air condition, and gas-powered vehicles. Electricity load includes loads consumed by residential buildings, public facilities, industry, business, and others.

Heating load.The heating area covers $90 \%$ of the building area, i.e., a total of 25.83 million $\mathrm{m}^{2}$, and has a coverage factor of heat-supply of $100 \%$ (refer with: Table 1). The simultaneity usage coefficient of the design heating load is 0.7 .

Table 1. Types of buildings and their heating areas, heating load data for load estimation, and heating rates

\begin{tabular}{c|c|c|c|c}
\hline Building type & $\begin{array}{c}\text { Construction area } \\
\left(10^{3} \mathrm{~m}^{2}\right)\end{array}$ & $\begin{array}{c}\text { Heating area } \\
\left(10^{3} \mathrm{~m}^{2}\right)\end{array}$ & $\begin{array}{c}\text { Heating load data for load } \\
\text { estimation }\left(\mathrm{W} / \mathrm{m}^{2}\right)\end{array}$ & $\begin{array}{c}\text { Rate } \\
(\%)\end{array}$ \\
\hline Residence & 20,140 & 18,126 & 36 & 70.17 \\
\hline Office & 2,010 & 1,809 & 40 & 7 \\
\hline Business & 4,890 & 4,401 & 85 & 1.46 \\
\hline $\begin{array}{c}\text { Culture and } \\
\text { entertainment }\end{array}$ & 420 & 378 & 50 & 3.87 \\
\hline Industry & 1,110 & 1,000 & 38 & 0.5 \\
\hline Others & 130 & 117 & $/$ & 100 \\
\hline Total & 28,700 & 25,830 & & 17 \\
\hline
\end{tabular}

The urban area of the eco-city accounts for $70 \%$ of the construction area, with a total of 20.09 million $\mathrm{m}^{2}$. According to the "Urban Heating Pipe Network Design Specifications" (CJJ 34-2010) [7], and the types of constructions in the region, comprehensive cooling would require a load of $75 \mathrm{~W} / \mathrm{m}^{2}$. The simultaneity usage coefficient of the design heating load for air conditioning is 0.7 .

According to the above specifications (CJJ 34-2010), the residential hot water use would require a daily average heating load of $12 \mathrm{~W} / \mathrm{m}^{2}$. The corresponding load for the other buildings is $10 \mathrm{~W} / \mathrm{m}^{2}$, and the hot water has a design load factor of 0.65 .

Based on the above analysis, the design heating load for this city in the short term and long term can be calculated (refer with: Table 2).

Table 2. Designed heating load $\left(10^{3} \mathrm{kWh}\right)$

\begin{tabular}{c|c|c}
\hline Type Year & 2017 & 2020 \\
\hline Heating & 5,450 & 10,090 \\
\hline Cooling & 5,690 & 10,540 \\
\hline Hot water & 890 & 1,640 \\
\hline
\end{tabular}


Gas load.The residential heat quota is $2300 \mathrm{MJ} /$ person $\cdot$ year, with a gasification rate of $100 \%$. According to the scenario, the industrial gas consumption is $1 \mathrm{~m}^{3} / 100 \mathrm{~m}^{2} \cdot$ day. The storage gas consumption indicator is $0.2 \mathrm{~m}^{3} / 100 \mathrm{~m}^{2} \bullet$ day, and the gas consumption of the combined cooling heating and power system using gas-fired air condition is $1 \mathrm{~m}^{3} / 100 \mathrm{~m}^{2} \cdot \mathrm{h}$. In the near future, gas-powered cars will not be considered, and the gasification rate of such vehicles will be considered only in the medium term and long term. Based on the above analysis, the gas load of this city in the short term and long term can be calculated (refer with: Table 3).

Table 3. Gas load

\begin{tabular}{|c|c|c|}
\hline Load & 2017 & 2020 \\
\hline Annual gas consumption $\left(10^{3} \mathrm{~m}^{3}\right)$ & 20,030 & 42,950 \\
\hline Annual average $\left(\mathrm{m}^{3} / \mathrm{d}\right)$ & 54,873 & 118,154 \\
\hline Calculated monthly average $\left(\mathrm{m}^{3} / \mathrm{d}\right)$ & 65,566 & 151,066 \\
\hline Consumption during peak hours $\left(\mathrm{m}^{3} / \mathrm{h}\right)$ & 9,316 & 18,587 \\
\hline
\end{tabular}

Electricity load.The electricity load in the eco-city is divided into five categories: residential, public facilities, industrial, commercial, and others. Load forecasting is performed according to the density data method(refer with: Table 4), and the effect of energy saving measures is determined. The prediction results in an electricity load of 108.14 million $\mathrm{kWh}$, with a load density of $20.1 \mathrm{MW} / \mathrm{km}^{2}$.

Table 4. Load density indicator for electricity supply

\begin{tabular}{|c|c|c|c|c|}
\hline \multicolumn{2}{|c|}{ Land Type } & Density indicator $\quad(\mathrm{W} /$ & Coefficient & Final indicator \\
\hline \multirow[t]{2}{*}{ Residence } & First class & 50 & $0.3-0.5$ & 18 \\
\hline & Second class & 60 & $0.3-0.5$ & 24 \\
\hline \multirow{2}{*}{$\begin{array}{c}\text { Public } \\
\text { facilities }\end{array}$} & Office & 60 & $0.7-0.8$ & 42 \\
\hline & Culture and entertainment & 60 & $0.7-0.8$ & 42 \\
\hline \multicolumn{2}{|r|}{ Industry } & 50 & $0.8-0.9$ & 40 \\
\hline \multicolumn{2}{|r|}{ Business } & 80 & $0.8-0.9$ & 60 \\
\hline \multirow[t]{4}{*}{ Others } & Park & 0.2 & -- & 0.2 \\
\hline & Storage & 10 & -- & 10 \\
\hline & Municipal facilities & 15 & -- & 15 \\
\hline & Mixed land & 60 & $0.5 \sim 0.8$ & 36 \\
\hline
\end{tabular}

Energy demand statistics.According to a reasonable scenario analysis, the projections for the demand in 2020 can be obtained for various energy sources; the energy demands are presented in Table 5.

Table 5. Total energy demand (2020)

\begin{tabular}{c|c}
\hline Type & Quantity $\left(10^{3} \mathrm{kWh}\right)$ \\
\hline Heating & $1,938,080$ \\
\hline Cooling & $1,425,060$ \\
\hline Hot water & $1,533,390$ \\
\hline Gas (excluding cogeneration, i.e., combined heat and power ) & 549,920 \\
\hline Electricity & $1,081,400$ \\
\hline
\end{tabular}

\section{Energy structure and evaluation}

Considering the energy situation and natural resources in the eco-city, the model for energy use is based on conventional energy, distributed energy, industrial waste heat, new energy, and renewable energy supplement; all these energy sources complement each other. This will ensure that the urban energy supply is safe and reliable, and reduce the carbon emissions in the eco-city.

Distributed energy systems. The core business district area is approximately $1,770,000 \mathrm{~m}^{2}$. The energy supply station uses natural gas as the fuel to provide combined cooling heating and power for 
the region, because of electrical safety requirements; the use of natural gas can reduce energy consumption by $60 \%$.

Industrial waste heat utilization system. The power plants in the eco-city can circulate low temperature water resource waste to improve their comprehensive energy efficiency, and reuse the waste heat. The urban power plants have a heating capacity of approximately 20 million $\mathrm{m}^{2}$, and account for the pipeline transport distance, heat, and other factors. An area of approximately 8.6 million $\mathrm{m}^{2}$ in the planned construction area can receive energy from Jinan city power plant using waste heat.

New energy and renewable energy systems. Assessment of solar photovoltaic, light, and heat resources. The eco-city is located in an area with a warm, temperate, and semi-humid monsoon climate. The average annual solar radiation intensity is $330 \mathrm{~W} / \mathrm{m}^{2}$; the average daily sunshine duration is $6.9 \mathrm{~h}$; the annual sunshine duration is $2,516.9 \mathrm{~h}$; the total annual radiation is $5120.50 \mathrm{MJ} / \mathrm{m}^{2}$; and the average solar radiation intensity is $330 \mathrm{~W} / \mathrm{m}^{2}$. The areas where the daily sunshine duration is greater than $6 \mathrm{~h}$, and the average monthly temperature is higher than $10^{\circ} \mathrm{C}$ for 239 days, are rich in solar energy resources, and have the potential to develop solar thermal and solar power industries.

The solar energy supply potential is calculated as follows:

Solar energy supply potential $(\mathrm{kWh})=$ land area $\times$ planned building density $\times$ annual total solar radiation $\left[\mathrm{MJ} /\left(\mathrm{m}^{2} \cdot \mathrm{a}\right)\right] \times$ usable roof area rate $(\%) \times$ solar cell area and usable roof area $(\%) \times$ solar power supply system conversion efficiency $(\%) \times$ additional coefficient for the building's photovoltaic curtain wall application(refer with: Table 6).

Table 6. Estimation coefficient for solar photovoltaic supply capacity

\begin{tabular}{c|c|c|c|c} 
Building type & $\begin{array}{c}\text { Roof } \\
\text { utilization } \\
\text { rate }\end{array}$ & $\begin{array}{c}\text { Battery pack / roof } \\
\text { area }\end{array}$ & $\begin{array}{c}\text { Photoelectric system } \\
\text { conversion efficiency }\end{array}$ & $\begin{array}{c}\text { Additional coefficient } \\
\text { for photovoltaic } \\
\text { curtain wall }\end{array}$ \\
\hline Business & $40 \%$ & $50 \%$ & $15 \%$ & 1.2 \\
\hline Office & $40 \%$ & $50 \%$ & $15 \%$ & 1.5 \\
\hline Market & $40 \%$ & $50 \%$ & $15 \%$ & 1.0 \\
\hline Community service & $20 \%$ & $50 \%$ & $15 \%$ & 1.0 \\
\hline Education & $60 \%$ & $50 \%$ & $15 \%$ & 1.0
\end{tabular}

Public buildings with solar panels can provide 0.19 billion $\mathrm{kWh}$ of electricity, considering only the provision of electricity demand for normal living, and ignoring the comprehensive energy efficiency of the solar photovoltaic systems, system investment recovery period, and other economic factors; the use of coal can be reduced by 0.69 million tons.

The large-scale utilization of solar water can be used in office buildings, primary and secondary schools. Centralized solar water heating system can be used in residence. The other users of solar water heating systems in commercial land can be demonstration projects. If the solar panels in the eco-city can provide approximately $22 \times 10^{8} \mathrm{MJ}$ of heat, this would cover $60 \%$ of the energy requirement of residential buildings.

Evaluation of shallow geothermal energy resources in the ground.The distribution of geothermal soil heat in the ecological city area is within 100-400 m from the surface; the temperature of the soil and groundwater equals the local average temperature, and is not affected by the environment or climate. Throughout the year, the temperature fluctuates, but the heat balance is maintained.

The shallow soil geothermal energy can be utilized for the areas with a smaller building density. According to the plans for the eco-city, the construction area for the low-density residential area, basic education zone, community services, and the other buildings with smaller building density lies in the northern part of the zone, with an area of $800,000 \mathrm{~m}^{2}$. 
Evaluation of shallow geothermal energy resources for surface water sources.Because of the large temperature difference between the river and the water source, the water source cannot be used for the water heat pump.

Wind energy resource assessment.Jinan has an effective wind energy density of 150-200 W/m². The road green lighting based on the wind-solar energy hybrid generation systems can be designed with the river landscape and the ventilation corridor.

New energy and renewable energy planning. New energy and renewable energy in this zone will generate approximately $100.14 \times 10^{7} \mathrm{kWh}$ by 2020 , with carbon dioxide emissions of 356,900 tons, a renewable energy utilization ratio of $15.19 \%$ (refer with: Table 7 ), waste heat utilization of $3.03 \%$, and clean energy utilization rate of $100 \%$.

Table 7. New energy and renewable energy replacement rate

\begin{tabular}{c|c|c}
\hline Energy type & Quality $\left(10^{3} \mathrm{kWh}\right)$ & Annual occupancy ratio (\%) \\
\hline Solar heating & 782,028 & 11.98 \\
\hline Photovoltaic & 197,100 & 3.02 \\
\hline Shallow soil geothermal energy & 6,700 & 0.15 \\
\hline Wind energy & 1,670 & 0.04 \\
\hline Total & 987,498 & 15.19 \\
\hline
\end{tabular}

\section{Conclusions}

To develop a scientific and rational renewable energy utilization plan for an eco-city, the energy demand should be forecasted, and the new and renewable energy resources should be assessed and combined with the conversion system performance characteristics. Analysis of construction sites should be conducted for renewable energy supplies and energy demand; and new and renewable energy engineering practices should be established based on the capacity of the new and renewable energy, preference, reliability, stability, technical difficulties, economic and environmental conditions, and other aspects.

\section{Acknowledgements}

This work was financially supported by the Natural Science Foundation of Shandong Province, China (ZR2014JL034) and the National Natural Science Foundation (51708334).

\section{References}

[1] Lee, G. and Jeong, Y.: Impact of Urban and Building Form and Microclimate on the Energy Consumption of Buildings- Based on Statistical Analysis. Journal of Asian Architecture and Building Engineering, 16 (3), 2017 ,p.565-572

[2] Jones, P., Li, X., Hou, S.: Urban Scale Energy Modelling in the Built Environment. Urban Environment Design, 101 (6), 2016 ,p.254-265

[3] Guiding opinions on the development of energy saving and land saving residential and public buildings (Jianke [2005] No. 78)

[4] Design Standard for Energy Efficiency of Residential Buildings in Severe Cold and Cold Zones (JGJ26-2010)

[5] Design standard for energy efficiency of public buildings (GB50189-2015)

[6] Shandong Province Residential Building Energy Efficiency Design Standards (DBJ 14-037-2012)

[7] Urban Heating Pipe Network Design Specifications (CJJ 34-2010) 